\title{
Gonadal mRNA Expression Levels of TGF $\beta$ Superfamily Signaling Factors Correspond with Post-Hatching Morphological Development in American Alligators
}

\author{
B.C. Moore H.J. Hamlin N.L. Botteri L.J. Guillette, Jr.
}

Department of Biology, Bartram Hall, University of Florida, Gainesville, Fla., USA

\section{Key Words}

Activin · Alligator $\cdot$ Development $\cdot$ Follistatin $\cdot$ FOXL2 .

GDF9 - Inhibin • Ovary · Testis

\begin{abstract}
Paracrine factor signaling regulates many aspects of vertebrate gonadal development. We investigated key ovarian and testicular morphological markers of the American alligator (Alligator mississippiensis) during the first 5 months posthatching and correlated gonadal development with mRNA expression levels of a suite of regulatory factors. In both sexes, we observed significant morphology changes, including ovarian follicle assembly and meiotic progression of testicular germ cells. Concomitant with these changes were sexually dimorphic and ontogenetically variable mRNA expressions. In ovaries, FOXL2, aromatase, and follistatin mRNA expression was greater than in testes at all ages. At one week after hatching, we observed ovarian medullary remodeling in association with elevated activin/inhibin $\beta A$ subunit, follistatin, and aromatase mRNA expressions. Three and 5 months following hatching and concomitant with follicle assembly, ovaries showed increased mRNA expression levels of GDF9 and the mitotic factor PCNA. In testes, the activin/ inhibin $\alpha$ and $\beta B$ subunit transcript levels were greater than in ovaries at all ages. Elevated testicular expression of GDF9
\end{abstract}

mRNA levels at 5 months after hatching aligned with increased spermatogenic activity. We propose that the mRNA expression levels and concomitant morphological changes observed here affect the establishment of alligator reproductive health and later fertility.

Copyright ๑ 2010 S. Karger AG, Basel

Timing of vertebrate gametogenesis shows striking differences. Most female germ cells from amniotes enter meiosis during embryonic or post-natal development, whereas male meiosis begins with puberty. Endocrine and paracrine factors regulate these transitions. Here we investigate key morphological markers of American alligator (Alligator mississippiensis) ovarian and testicular development during the first 5 months post-hatching and correlate somatic and germ cell development with mRNA expression levels of a suite of gonadal regulatory factors. This comparison establishes sexually dimorphic expressions of many of these gonadal regulatory factors and explores ontogenetic changes in mRNA expression levels both within and between sexes during this period of substantial morphological development.

Ovarian follicle assembly is crucial to adult fertility. Among vertebrates, there are considerable differences in the timing of initial follicular somatic-germ cell interac-

\section{KARGER}

() 2010 S. Karger AG, Basel

Fax +4161306 1234

E-Mail karger@karger.ch

www.karger.com
Accessible online at:

www.karger.com/sxd
Brandon C. Moore

Center for Bioenvironmental Reseach, Tulane University

1430 Tulane Ave., SL-3

New Orleans, LA 70112-2699 (USA)

Tel. +1 504862 8454, Fax +1 504988 6428, E-Mail bmoore2@tulane.edu 
tions. As oogonia enter into meiotic prophase I, cytoplasmic bridges between germ cell syncytia breakdown [Pepling et al., 1999; Matova and Cooley, 2001; Pepling, 2006]. Subsequently, follicle assembly occurs after oocytes enter into diplotene arrest. Mammalian follicle assembly occurs either in utero (e.g. human, cow, pig), immediately after birth (e.g. rat, mouse), or during an extended postnatal immature period (e.g. rabbit, dog). Non-mammalian vertebrates show similar variability. Birds assemble follicles during the post-hatching period [Callebaut, 1968a, b]. Some reptiles form follicles as embryos [Forbes, 1956]; for example follicle assembly occurs prior to hatching in many species of turtles [Pieau and Dorizzi, 2004]. In the American alligator, we have demonstrated that follicle assembly occurs over a relatively extended posthatching period [Moore et al., 2008]. Follicles with complete follicular cell layers are not observed until three months after hatching. Here, we expand these morphological observations to 5 months post-hatching and investigate concomitant mRNA expression changes of factors involved in gonadal development, germ cell maturation, and ovarian follicle assembly.

Within seminiferous tubules, male germ cells mature in three main phases: mitotic proliferation of spermatogonia, meiotic maturation of spermatocytes, and production of mature spermatozoa through spermiogenesis. During maturation, germ cells move from the juxta-epithelial, basal compartment towards the central, luminal compartment. Few researchers have investigated alligator testicular development [Gribbins et al., 2006]; though it is clear wild alligators have a prolonged and delayed maturation, followed by an extended pubescent period [Lance, 2003]. Alligators are seasonal breeders and, in the wild, male alligators with snout-vent lengths (SVL) $>100$ $\mathrm{cm}$ produce sperm [Joanen and McNease, 1980]. Therefore, estimated sexual maturity in wild alligators is 10 years of age or greater. However, testosterone cyclicity has been observed in wild juvenile alligators with SVL $>38$ $\mathrm{cm}$ [Rooney et al., 2004]. We have hypothesized that seasonal reproductive cyclicity - based on seasonal changes in plasma sex steroid hormone concentrations - begins years before the achievement of 'sexual maturity'. Male alligator puberty most likely is a neuroendocrine event, like that described in mammals and birds. In many reptiles, hypophysectomy leads to testicular degeneration [van Tienhoven, 1983], but exogenous gonadotropins restore spermatogenesis [Licht and Pearson, 1969]. Furthermore, gonadotropin or androgen treatments of immature male alligators induces testicular development [Forbes, 1937; Ramaswam and Jacob, 1965] and dramatic increases in plasma sex steroid hormone concentrations [Edwards et al., 2004]. We have observed that ovarian development accelerates in animals held under optimum, laboratory conditions [Moore et al., in press]. Under these conditions, the timing of ovarian follicle formation more closely matches development observed in juvenile chickens [Moore et al., 2008]. Here, we demonstrate that under laboratory conditions, alligator testes exhibit profound somatic and germ cell maturation that correlates with changes in mRNA levels of factors associated with testicular maturation.

Ovarian and testicular development requires somatic and germ cell interactions to regulate processes such as proliferation, differentiation, and maturation. Paracrine and autocrine signaling modulates many of these processes. Transforming growth factor- $\beta$ (TGF $\beta$ ) superfamily ligand subunits dimerize to produce signaling factors, such as activins and inhibin, that are vital to reproductive maturation and function [de Kretser et al., 2004; Drummond, 2005; Pangas et al., 2007; Barakat et al., 2008]. The production of activins, inhibins, and follistatin mediates activin signaling. Activin ligands act as agonists, work through membrane-bound activin receptor complexes, stimulate Smad-mediated secondary messenger cascades, and ultimately modulate gene expression [Ethier and Findlay, 2001]. Homo- or heterodimerization of $\beta$ subunits, $\beta A$ (INHBA) or $\beta B$ (INHBB), form activin A ( $\beta A$ $\beta A)$, activin $B(\beta B-\beta B)$, or activin $A B(\beta A-\beta B)$. Ovarian activin signaling regulates follicle formation and initial follicle pool size [Bristol-Gould et al., 2006]. In testes, activin A is a paracrine factor regulating Sertoli cell number in the developing testes [Buzzard et al., 2003]. Loss of activin signaling in mice decreases numbers of spermatogonia and sperm production [Kumar et al., 2001].

Synthesis of inhibins or follistatin antagonizes activin signaling. Inhibins, activin receptor binding and activation antagonists, are heterodimers of a $\beta$ subunit and an $\alpha$ subunit (INHA) forming either inhibin $\mathrm{A}(\beta \mathrm{A}-\alpha)$ or inhibin $\mathrm{B}(\beta \mathrm{B}-\alpha)$. Ovarian inhibin expression is minimal prior to puberty [Raivio and Dunkel, 2002]; however, it is vital to testicular formation and maintenance [Loveland et al., 2007]. Follistatin (FST) is a TGF $\beta$ ligand antagonist that binds and neutralizes activins. It is a somatic-cellproduced factor expressed in greater concentrations in embryonic mouse ovaries than testes [Menke and Page, 2002], though FST plays a role in both ovarian and testicular development [de Kretser et al., 2004; Yao et al., 2004; Yao, 2005].

In addition to activin/inhibin signaling components, we examined the mRNA expression levels of additional 
factors associated with gonadal differentiation and/or maturation. Growth differentiation factor 9 (GDF9) is a germ cell-secreted TGF $\beta$ superfamily ligand that regulates ovarian folliculogenesis through directing granulosa cell proliferation and differentiation [Dong et al., 1996; Carabatsos et al., 1998; Johnson et al., 2005]. Proliferating cell nuclear antigen (PCNA) is a sliding ring clamp that interacts with DNA polymerase during DNA replication and expression is maximal around the $S$ phase of the cell cycle [Krishna et al., 1994]. Ovarian formation is a directed, active process [Ottolenghi et al., 2005, 2007; Yao, 2005] and gonadal expression of the transcription factor forkhead box L2 (FOXL2) is a sexually dimorphic, early molecular marker of ovary-specific sex differentiation [Loffler et al., 2003; Uhlenhaut and Treier, 2006; Rhen et al., 2007]. Expression of FOXL2 is vital for primordial follicle pool formation [Schmidt et al., 2004], granulosa cell differentiation [Schmidt et al., 2004], and activates aromatase (CYP19A1) gene transcription [Hudson et al., 2005; Pannetier et al., 2006].

Here, we exploit the relatively slow development of the alligator ovary to study changes in gene expression levels concomitant with morphological development. Additionally, we compare and contrast concomitant testicular morphological development and gene expression. This study establishes sexual dimorphic gene expression patterns and ontogenetic changes in morphology that begin at hatching and provides a baseline for comparative studies as well as future integrative studies of the function of the alligator gonad.

\section{Materials and Methods}

We obtained American alligator (Alligator mississippiensis, Daudin, 1801) eggs from nests in the Lake Woodruff National Wildlife Refuge (Permit \#WX01310) prior to the period of temperature-dependent sex determination [Ferguson and Joanen, 1983 ] in June 2006. At the University of Florida, eggs $(n=105)$ from seven clutches were candled to assess viability and divided between two incubation temperatures: $30^{\circ} \mathrm{C}$ that produces females $(n=55)$ and $33^{\circ} \mathrm{C}$ that produces males $(n=50)$. Within each incubation temperature group, we systematically arranged eggs in trays of damp moss. During incubation, we rotated trays to minimize possible clutch or incubator position biases. The total hatching success rate was $84 \%$ : $82 \%$ of animals from $30^{\circ} \mathrm{C}(\mathrm{n}=45)$ and $86 \%$ of animals from $33^{\circ} \mathrm{C}(\mathrm{n}=43)$.

Animal procedures conformed to an IACUC approved protocol. Following hatching, animals were housed within a temperature-controlled animal room in tanks $\left(\sim 20\right.$ neonates $\left./ 0.7 \mathrm{~m}^{3}\right)$ and experienced a 16:8 photoperiod with heat lamps for basking. Ambient room temperatures ranged from 27 to $31^{\circ} \mathrm{C}$. Alligators hatch with a relatively large residual yolk mass; thus, ad libitum hatch- ling feeding started 10 days after hatching with a small pellet size, commercial crocodilian diet (Mazuri, \#5MG1).

Tissues were collected from subsets of alligators after a lethal dose of sodium pentobarbital at: one week $\left(30^{\circ} \mathrm{C} \mathrm{n}=12,33^{\circ} \mathrm{C}\right.$ $\mathrm{n}=10), 1$ month $\left(30^{\circ} \mathrm{C} \mathrm{n}=11,33^{\circ} \mathrm{C} \mathrm{n}=9\right), 3$ months $\left(30^{\circ} \mathrm{C} \mathrm{n}=\right.$ $\left.10,33^{\circ} \mathrm{C} \mathrm{n}=8\right)$, and 5 months post-hatching $\left(30^{\circ} \mathrm{C} \mathrm{n}=11,33^{\circ} \mathrm{C}\right.$ $\mathrm{n}=10$ ). At necropsy, one gonad from alternating sides was removed and stored in RNAlater (Ambion) at $-20^{\circ} \mathrm{C}$ until RNA extraction. The contralateral gonad and underlying tissues were Bouin's fixed for $24 \mathrm{~h}$, underwent standard paraffin histology, were sectioned parasagittally at $6 \mu \mathrm{m}$, and stained with periodic acid (PAS)-alcian blue ( $\mathrm{pH} 2.5$ ) with hematoxylin counterstaining. Histological sections were examined using an Olympus BH-2 light microscope and photographed with a Pixelink PL-B623CU 3.0 megapixel digital camera.

Microscopic examination showed all gonads from alligators incubated at $30^{\circ} \mathrm{C}$ were ovaries whereas $68 \%$ of gonads from animals incubated at $33^{\circ} \mathrm{C}$ were testes. Of the females produced from the $33^{\circ} \mathrm{C}$ incubation, $92 \%$ came from three of the seven egg clutches collected for the experiment. We present results only from gonads of $30^{\circ} \mathrm{C}$ females and $33^{\circ} \mathrm{C}$ males in this manuscript ( $\mathrm{n}$ at $30^{\circ} \mathrm{C} / 33^{\circ} \mathrm{C}$ : 1 week $12 / 8,1$ month $11 / 6,3$ months $10 / 8$, and 5 months 11/7). Body masses (BM) were recorded prior to necropsy (average age of groups at measurement in days: 1 week $=4.5$ days, 1 month $=28.1$ days, 3 months $=88.5$ days, and 5 months $=145.6$ days).

While examining ovarian histology, we observed morphological changes in both cortex and medulla. We characterized states of oogenesis and folliculogenesis at each time point in our study. Chromatin and cytoplasmic morphologies determined various oocyte stages of prophase I. Additionally, oocyte stages were identified according to a system that incorporates both meiotic characteristics and extent of folliculogenesis [Uribe and Guillette, 2000]. Stage-1 (S1) oocytes have a mean diameter of approximately $10 \mu \mathrm{m}$, exhibit fibrillar chromatin, and are in loose association with follicular cells. Stage-2 (S2) oocytes have a mean diameter of approximately $25 \mu \mathrm{m}$, an incomplete follicular layer of somatic cells, and diplotene nuclei that often display chiasma, lampbrush chromosomes, and several nucleoli. Stage-3 (S3) oocytes, also diplotene, are distinctly larger in diameter (120-200 $\mu \mathrm{m})$, often display pronounced Balbiani bodies and lampbrush chromosomes, and possess a complete follicular layer of granulosa as well as a developing layer of surrounding thecal cells.

We observed morphological changes in testicular histology of the seminiferous cords and interstitial spaces. With insight from the recent characterization of adult alligator germ cell maturation [Gribbins et al., 2006], cellular morphology and location within tubules characterized germ cell maturation.

RNA isolation and reverse transcription procedures for alligator gonadal tissues have been previously reported from our laboratory [Milnes et al., 2008]. Quantitative real-time PCR (Q-PCR) has been used to measure mRNA expression in the American alligator [Katsu et al., 2004; Gunderson et al., 2006; Kohno et al., 2008]. Table 1 reports primer sequence information, annealing temperatures, and accession numbers. Q-PCR was performed using the MyiQ single color detection system (BioRad) following manufacturer's protocol using iQ SYBR Green Supermix (Bio$\mathrm{Rad}$ ) in triplicate reaction volumes of $15 \mu \mathrm{l}$ with $0.6 \mu \mathrm{l}$ of RT product and specific primer pairs. We calculated expression levels of mRNA using gene specific, absolute standard curves, which con- 
Table 1. Q-PCR Primer data

\begin{tabular}{|c|c|c|c|c|}
\hline Gene & $\begin{array}{l}\text { Forward primer }\left(5^{\prime}-3^{\prime}\right) \\
\text { Reverse primer }\left(5^{\prime}-3^{\prime}\right)\end{array}$ & $\begin{array}{l}\text { Annealing tempera- } \\
\text { ture, }{ }^{\circ} \mathrm{C}\end{array}$ & $\begin{array}{l}\text { Product size } \\
\text { bp }\end{array}$ & Accession No. \\
\hline$I N H B A$ & $\begin{array}{l}\text { ACCCACAGGTTACCGTGCTAA } \\
\text { GCCAGAGGTGCCCGCTATA }\end{array}$ & 63.8 & 67 & DQ101152 \\
\hline$I N H B B$ & $\begin{array}{l}\text { GGGTCAGCTTCCTCCTTTCAC } \\
\text { CGGTGCCCGGGTTCA }\end{array}$ & 64.7 & 70 & DQ010153 \\
\hline INHA & $\begin{array}{l}\text { ACAATCCACTTGTCCCAGCC } \\
\text { CAACTGCCACCGCGC }\end{array}$ & 70.0 & 68 & DQ010151 \\
\hline FST & $\begin{array}{l}\text { CGAGTGTGCCCTCCTCAAA } \\
\text { TGCCCTGATACTGGACTTCAAGT }\end{array}$ & 66.5 & 65 & DQ010156 \\
\hline FOXL2 & $\begin{array}{l}\text { ATCAGCAAGTTCCCCTTCTAC } \\
\text { GCCTTTCTCGAAAATGTCCTC }\end{array}$ & 65.0 & 171 & EU848473 \\
\hline CYP19A1 & $\begin{array}{l}\text { CAGCCAGTTGTGGACTTGATCA } \\
\text { TTGTCCCCTTTTTCACAGGATAG }\end{array}$ & 63.8 & 79 & AY029233 \\
\hline GDF9 & $\begin{array}{l}\text { TCAGTTTCCTCCTCTTCTCCAATT } \\
\text { ACACACTTGGCTAGAAGGATCATTC }\end{array}$ & 63.0 & 78 & DQ015675 \\
\hline PCNA & $\begin{array}{l}\text { AGCAGAAGACAATGCAGACAC } \\
\text { CTAAGCCATATTGGAGATGCA }\end{array}$ & 62.0 & 199 & FJ824113 \\
\hline
\end{tabular}

tain the target cDNA at known concentrations. The use of absolute standard curves allows statistical comparisons of mRNA expression levels of different genes within and among samples. Sample means were normalized using ribosomal protein L8 (RPL8) expression [Kohno et al., 2008; Milnes et al., 2008].

JMP for Windows version 7.0.2 (SAS Institute, Cary, NC) performed all statistical analyses. Morphometric data were log transformed and gene expression ratios were arcsin transformed to achieve homogeneous variances, as needed. Significance was set at $\mathrm{p}<0.05$. We analyzed data by two-way ANOVA and employed least square means Tukey-Kramer post-hoc comparisons, when appropriate, comparing body measurements and relative mRNA expressions by sex, age, and sex by age. To investigate possible interaction between mRNA expressions, we performed selected linear regressions within sex and age groups.

\section{Results}

\section{Growth and Gonadal Morphology}

Under our laboratory animal room conditions (16:8 photoperiod and ambient room temperatures ranging from 27 to $31^{\circ} \mathrm{C}$ ), alligator growth was robust over the period of this study (age-mean male BM (g) \pm SEM, female BM \pm SEM): 1 week $-56.9 \pm 4.4,56.7 \pm 4.5 ; 1$ month $-80 \pm 19,103 \pm 12 ; 3$ months $-412 \pm 56,493$ $\pm 58 ; 5$ months $-901 \pm 118,985 \pm 81$. At 5 months, the average alligator $\mathrm{BM}$ was more than 15 times greater than that recorded at 1 week of age. At 1 and 3 months, the female BM was greater than male BM ( $p=0.009$ for each).
Alligator ovaries are composed of a cortex of germ and somatic cells overlying a medulla of connective tissue and lacunae containing secretory materials (fig. 1A-D). Mesonephric and adrenal tissues juxtapose gonadal tissues (fig. 1A). During the 5 months after hatching, we observed cortex expansion and follicle assembly. At 1 week and 1 month after hatching, the cortex is composed of oogonia nests, $\mathrm{S} 1$ oocytes, and somatic pre-follicular cells (fig. 1A, B). The medulla fragments and lacunae expand during this period. Cortex thickness increases at 3 and 5 months after hatching, concomitant with enlarging germ cell nests and follicle assembly around S2 and S3 oocytes (fig. 1C, D). The cytoplasm of S2 and S3 oocytes contains Balbiani bodies. Follicles containing S3 oocytes have a full complement of granulosa cells and, externally, a thin layer of fibroblast-forming thecal layers (fig. 1G, H). At 5 months, $\mathrm{S} 3$ oocytes were more numerous than at 3 months and we continued to observe oogonia with mitotic chromatin within germ cell nests (fig. $1 \mathrm{H}$ ).

From 1 week to 1 month after hatching, alligator testes are characterized by seminiferous cords lined with Sertoli cells and spermatogonia $A$ and are separated by sparse interstitial tissues (fig. 2A, B, E and F). At 3 months after hatching, we observed spermatogonia $B$ above the basement membrane, primary spermatocytes with more central locations within tubules, and an increase in interstitial tissues with clearly observed Leydig cells (fig. 2C, G). At 5 months after hatching, seminiferous tubules con- 
Fig. 1. Ovary of Alligator mississippiensis at 1 week (A, E), 1 month (B, F), 3 months $(\mathbf{C}, \mathbf{G})$, and 5 months $(\mathbf{D}, \mathbf{H})$ after hatching in parasaggital view (A-D) and enlarged detail (E-H). At 1 week after hatching the ovarian cortex contains nests of germ cells (N) along the coelomic $(*)$ border. These nests contain Stage-1 oocytes (S1) in close interaction with pre-follicular cells $(\mathrm{pF})$. Underlying the cortex, lacunae (L) form within degenerating medullary cords. The gonad overlies mesonephric (M) and adrenal tissues (A). At 1 month after hatching, the medullary lacunae (L) have expanded. At 3 and 5 months after hatching, the cortex contains Stage-2 (S2) and -3 oocytes (S3), displaying Balbiani bodies (B). S3 oocytes are contained in follicles with a complete complement of squamous to cuboidal follicular cells (F). Germ cell nests continue to present oogonia with mitotic chromosomes (Gch) at 5 months after hatching. Scale bars $=50 \mu \mathrm{m}$.
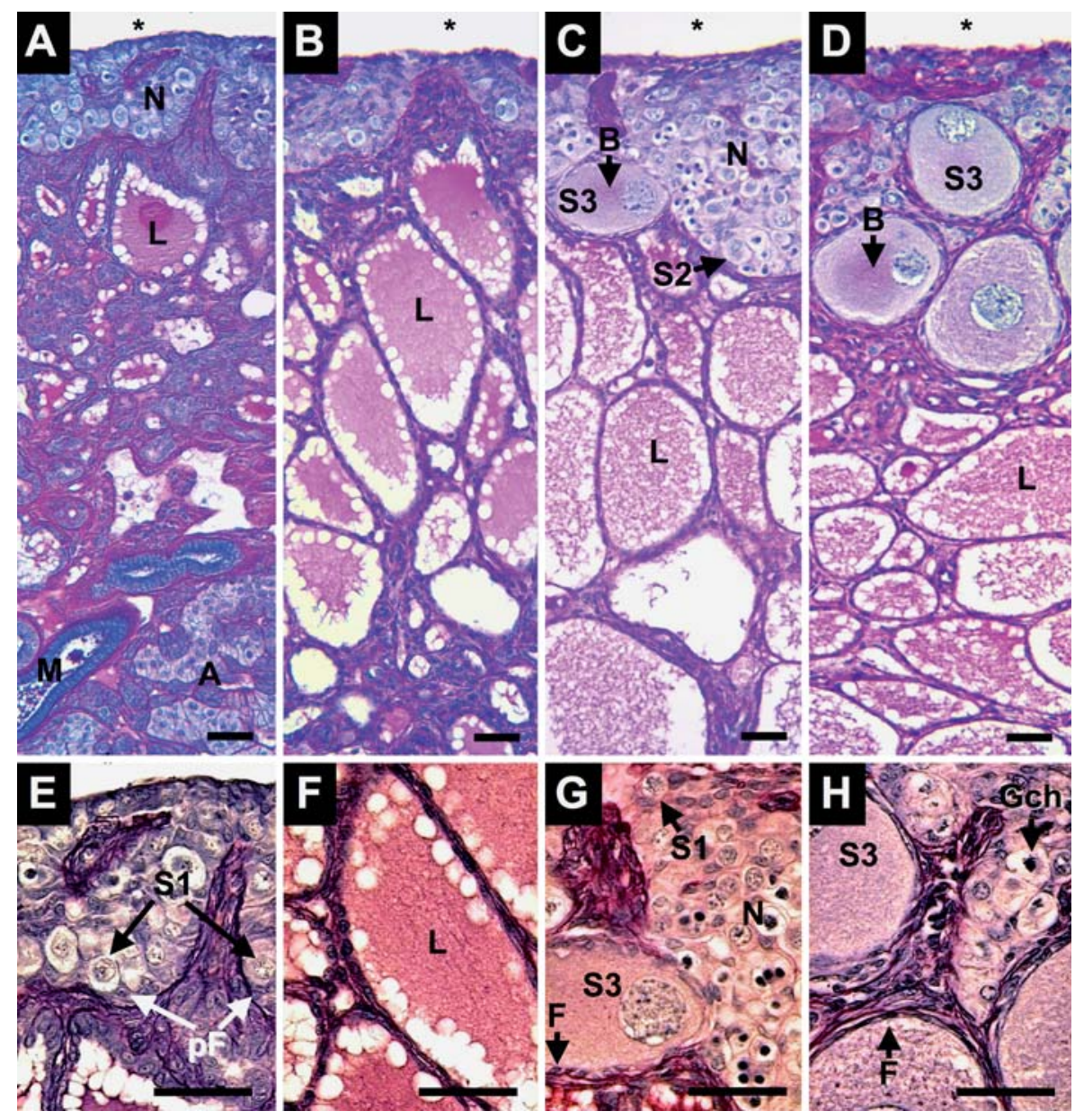

tained centrally located round spermatids along with spermatogonia and spermatocytes (fig. 2D, H). Interstitial tissues and Leydig cell clusters continued to enlarge.

\section{Gene Expression}

Expression levels of RPL8 were not different among sexes, ages, or sex by age comparisons. INHBA (fig. 3A, $\mathrm{B} ; \mathrm{p}=0.003$ ), $I H B B B$ (fig. $3 \mathrm{C}, \mathrm{D} ; \mathrm{p}=0.004$ ), INHA (fig. 3E, F; p < 0.001), FST (fig. 3G, H; p < 0.001), GDF9 (fig. 3I, J; $\mathrm{p}=0.42$ ), PCNA (fig. $3 \mathrm{~K}, \mathrm{~L} ; \mathrm{p}=0.039$ ), and CYP19A1 (fig. 3O, P; $\mathrm{p}=0.008$ ) mRNA expression levels showed significant sex by age interactions. We observed sexually dimorphic expression patterns that were uniform across all ages. Female FOXL2 mRNA expression levels were greater than male expression levels, which were at the limit of detection (fig. 3M, N; p >0.001). On the other hand, testicular expression levels of INHBB and INHA mRNA were greater than ovarian levels (fig. 3C-F) and female INHA expression levels were at the limit of detec- tion (fig. 3E). Testicular levels of these transcripts trended to decrease as age increased (fig. 3D, F). Conversely, ovarian FST and CYP19A1 mRNA expression levels were greater than that observed in testicular tissue (fig. 3G, $\mathrm{H}$ and $3 \mathrm{O}, \mathrm{P}$, respectively). Testicular INHBB levels were over an order of magnitude greater than INHBA levels (fig. 3B, D). Ovarian INHBA, INHBB, FST, and CYP19A1 mRNA expression levels shared a similar expression pattern: decreased expression levels between 1 week and 1 month, a trend to increase at 3 months, and subsequently decreased levels at 5 months (fig. 3A, C, G, and O). Ovarian GDF9 and PCNA mRNA expression levels increased with age between 1 and 3 months (fig. 3I, K). Testicular GDF9 mRNA expression was greater in months 3 and 5 than at 1 week and 1 month (fig. 3J) and PCNA mRNA expression levels showed an increasing trend between 3 and 5 months after hatching (fig. 3L).

Linear regression of ovarian FOXL2 by CYP19A1 mRNA expression by age groups showed significant lin- 
Fig. 2. Testis of Alligator mississippiensis at 1 week (A, E), 1 month (B, F), 3 months (C, G), and 5 months $(\mathbf{D}, \mathbf{H})$ after hatching in parasagittal view (A-D) and enlarged detail (E-H). The coelomic $\left({ }^{*}\right)$ border is defined by a tunica $(\mathrm{T})$ that thickens with age. The gonads contain well-defined seminiferous tubules $(\mathrm{S})$ lined with spermatogonia A (SA) and overlie mesonephros tissue $(\mathrm{M})$ containing glomeruli (Gl) and mesonephric ducts (Md) and adrenal tissues (A). At 3 and 5 months after hatching, interstitial tissues (I) between tubules expand and present Leydig cells (Le). At 3 months after hatching, seminiferous tubules present spermatogonia A and B (SA, SB) and primary spermatocytes (PS). At 5 months after hatching, tubules contain germ cells including round spermatids (Rst). Scale bars $=50 \mu \mathrm{m}$.
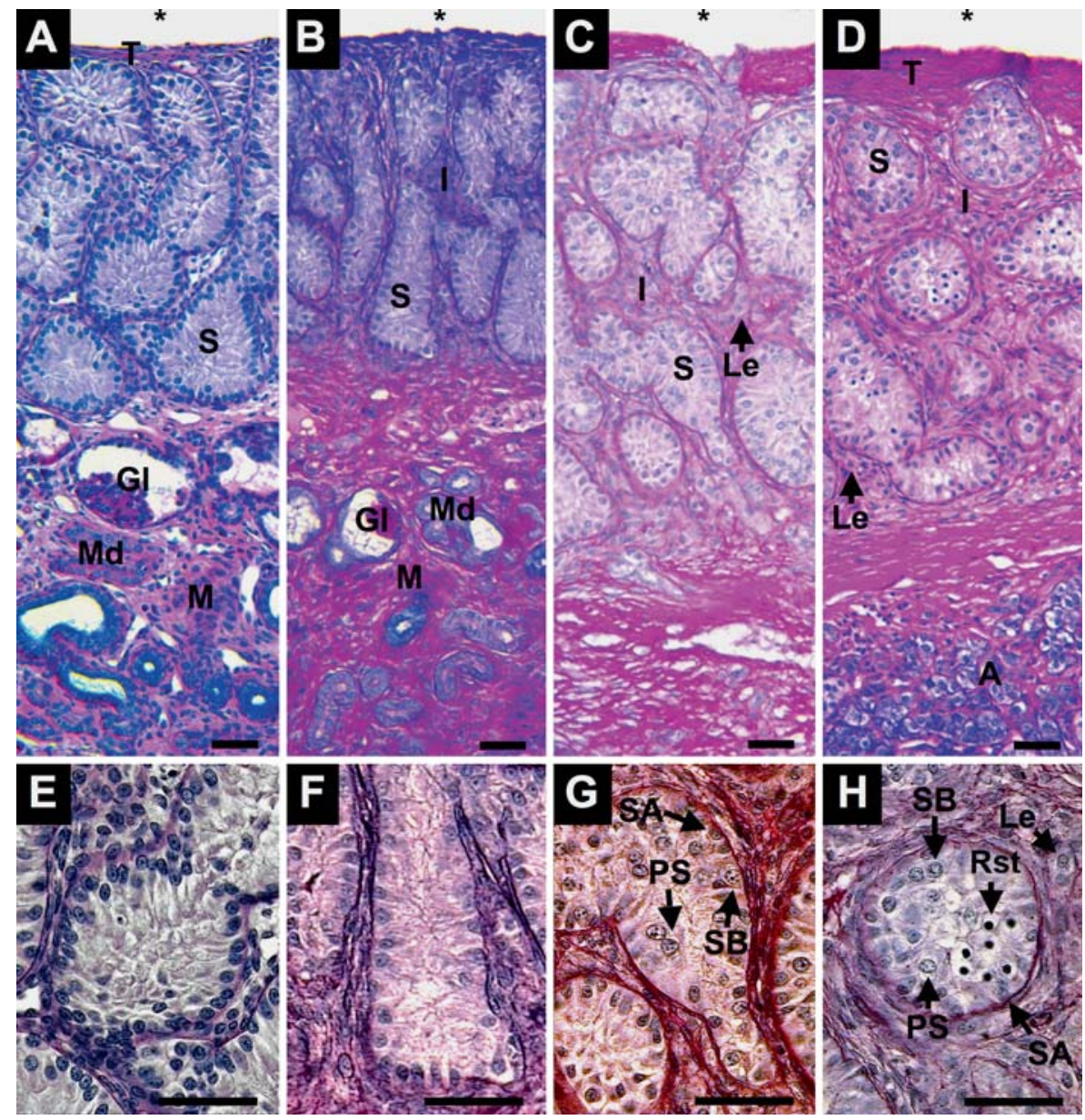

ear relationships at 1 week $\left(\mathrm{p}=0.005, \mathrm{R}^{2}=0.56\right)$ and 3 months $\left(\mathrm{p}=0.001, \mathrm{R}^{2}=0.71\right)$, however not at 1 month $\left(\mathrm{p}=0.40, \mathrm{R}^{2}=0.02\right)$ and 5 months $\left(\mathrm{p}=0.18, \mathrm{R}^{2}=0.19\right)$.

\section{Discussion}

During the first 5 months after hatching, we observed a considerable increase in body mass, significant changes in gonadal morphology, development of male and female germ cells, and sex-specific and ontogenetically variable mRNA expression patterns. As observed in previous studies, newly hatched alligator gonads are not quiescent [Guillette et al., 1994; Milnes et al., 2008; Moore et al., 2008]. Analogous to the importance of appropriate mammalian follicle assembly [Bristol-Gould et al., 2006] or post-natal Sertoli cell proliferation [Buzzard et al., 2003], we propose that the mRNA expression levels and concomitant morphological changes observed here affect the establishment of alligator reproductive health and later fertility.

Appropriate activin signaling is vital for both ovarian and testicular maturation [Loveland et al., 2007; Pangas et al., 2007]. In this study, we observed sexually dimorphic expressions of INHBB, INHA, and FST mRNA in alligator hatchling gonads. In mammals and birds, ovarian INHA mRNA expression prior to puberty is minimal [Raivio and Dunkel, 2002; Billiar et al., 2003; da Silva et al., 2004; Onagbesan et al., 2004]; however, embryonic and immature expression is vital to testicular formation and maintenance [Drummond et al., 2004; Loveland et al., 2007]. The absence of INHA in ovaries allows an activin-signaling milieu critical for germ cell survival and proliferation [da Silva et al., 2004; Bristol-Gould et al., 2006]. In male humans and rodents, INHA mRNA is primarily expressed in Sertoli cells and a post-natal inhibin B peak is hypothesized to result from Sertoli cell proliferation [Meachem et al., 2001; Buzzard et al., 2004; Bara- 

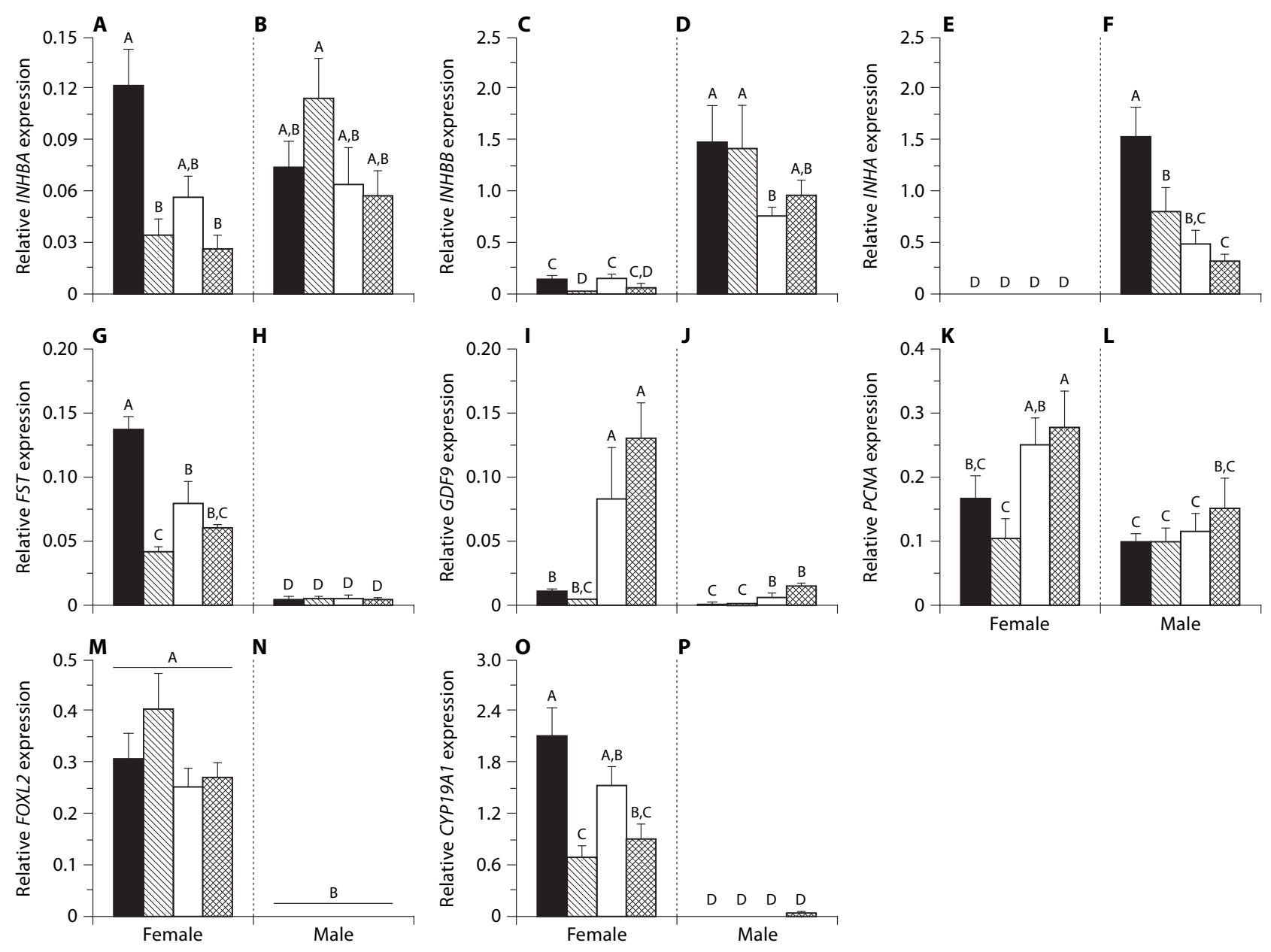

Fig. 3. Mean ( \pm SEM) gonadal mRNA expression of INHBA (A, B), INHBB (C, D), INHA (E, F), FST (G, H), GDF9 (I, J), PCNA (K, $\mathbf{L})$, FOXL2 (M, N), CYP19A1 $(\mathbf{O}, \mathbf{P})$ in female $(\mathbf{A}, \mathbf{C}, \mathbf{E}, \mathbf{G}, \mathbf{I}, \mathbf{K}, \mathbf{M}$, and $\mathbf{O}$ ) and male (B, D, F, H, J, $\mathbf{L}, \mathbf{N}$, and $\mathbf{P}$ ) alligators. Days after hatching: black bars $=7$, diagonal lined bars $=30$, white bars $=$
90 , crosshatched bars $=150$. All sample means were normalized using ribosomal protein L8 (RPL8) expression. Different letters above the bars of each graph of mRNA transcript levels indicate statistical significance at $\mathrm{p}<0.05$ across both ages and sexes. kat et al., 2008]. Sertoli cells proliferate for seven weeks after hatching in chicken [Bozkurt et al., 2007]. Our observations of post-hatching elevated testicular INHA and $I N H B B$ mRNA levels are in line with these observations. We propose that decreasing testicular INHA and INHBB mRNA levels over time could represent either a cessation of Sertoli cell proliferation or a decrease in concentration of Sertoli cell-derived mRNA in cDNA samples due to increased mRNA from increasing numbers of germ and interstitial cells.

In the developing mouse testes, INHBB mRNA expression is greater than in ovaries [Yao et al., 2006]. Ele- vated INHBB levels modulate the formation of testis-specific vascularity, putatively through production of activin $B$ or inhibin $B$. This is in agreement with sexually dimorphic INHBB mRNA levels observed in post-hatching alligators. Further, the activin antagonist Fst is expressed at greater levels in embryonic mouse ovary than testis [Menke and Page, 2002], promotes the survival of meiotic germ cells in the cortex, and antagonizing testis-specific, INHBB-mediated vascular formation [Yao et al., 2004]. Conversely, FST mRNA overexpression leads to Leydig cell hyperplasia, an arrest of spermatogenesis, and seminiferous tubular degeneration [Guo et al., 1998]. El- 
evated testicular INHA and INHBB and elevated ovarian FST mRNA levels are in line with mammalian gene expression patterns that result in appropriate sex development and maintenance.

We observed a robust increase in GDF9 mRNA expression in 3-and 5-month-old ovaries. This increase coincided with the assembly of complete follicles around S3 oocytes. This is in agreement with the reported role of GDF9 in primary and primordial follicles which is to promote granulosa and possibly thecal cell proliferation and differentiation [Trombly et al., 2009]. Though expressed in greater amounts in ovaries, GDF9 mRNA expression has been localized in human testes and rodent spermatocytes and spermatids [Fitzpatrick et al., 1998] and regulates Sertoli cell function [Nicholls et al., in press]. In agreement with these findings, we observed increased GDF9 mRNA expression concomitant with initiation of spermatogenesis at 3 and 5 months after hatching. Further, rat testicular GDF9 expression was greatest in round spermatids [Nicholls et al., 2009]. We observed the greatest mean expression of GDF9 mRNA in alligator testes at 5 months, the time round spermatids were first observed.

If GDF9 mRNA expression promotes somatic cell proliferation, we hypothesized that we could detect an associated change in mitotic activity. As a molecular marker of mitotic activity, we quantified levels of gonadal PCNA mRNA expression. Increased PCNA protein in granulosa cells marks the earliest stages of follicle growth [Oktay et al., 1995]. In testes, PCNA protein marks the proliferation of Sertoli cells and spermatogonia [Schlatt and Weinbauer, 1994]. When compared to levels at 1 month, we observed increased ovarian PCNA mRNA expression at 3 and 5 months after hatching. During these later developmental periods, the ovarian cortex expanded with the presence of enlarged follicles. Follicular, thecal, and germ cell proliferation could contribute to elevated ovarian PCNA mRNA levels. In alligator testes, we observed a trend toward greater PCNA mRNA levels, though this increase was not statistically significant.

Among vertebrates, FOXL2 expression is vital for ovarian development [Ottolenghi et al., 2007] and has high amino acid sequence conservation in the forkhead domain [Oshima et al., 2008]. In FOXL2 knockouts, meiotic prophase oocytes form, but FST mRNA expression is decreased and primordial follicles do not assemble [Uda et al., 2004; Ottolenghi et al., 2005]. As expected, we observed highly dimorphic FOXL2 mRNA in juvenile alligator gonads. In pre-follicular chicken ovaries, FOXL2 and aromatase expression co-localize in the medulla
[Govoroun et al., 2004] and positively correlate with expression levels during embryonic ovarian development in turtles [Rhen et al., 2007] and chicken [Govoroun et al., 2004]. FOXL 2 transcription factor binds to and regulates the CYP19A1 promoter [Pannetier et al., 2006; Wang et al., 2007]. Further, CYP19A1 transcript expression could potentiate a positive feedback on FOXL2 expression via an estradiol-17 $\beta$ mechanism [Hudson et al., 2005].

Similar to FOXL2 transcript levels, in this study we observed sexually dimorphic juvenile alligator gonadal CYP19A1 mRNA expression levels. In support of FOXL2 regulation of CYP19A1 mRNA expression, we observed positive correlations between expression levels of these factors at 1 week and 3 months after hatching, however not at 1 month or 5 months. We propose that because 1 week after hatching encompasses the greatest period of medullary fragmentation and 3 months marks the first observation of thecal cell layers around S3 oocytes completing follicle assembly that greater estrogenic signaling characterizes these periods. Gonadal aromatase activity is sexually dimorphic in embryonic alligator gonads and ovarian aromatase activity increases from sex determination until hatching [Smith et al., 1995]. In turtles, ovarian aromatase activity falls after hatching, and then rises during the following months [Belaid et al., 2001]. Estrogens impede testicular cord formation and possibly maintain female turtle medullary morphology and gene expression after sex differentiation [Belaid et al., 2001; Pieau and Dorizzi, 2004]. We hypothesize elevated CYP19A1 mRNA levels at 1 week after hatching, driven by FOXL2 mRNA expression, plays a roll in alligator medullary restructuring.

In chicken hatchlings, steroidogenic cells migrate from the medulla into the cortex and surround assembling follicles as theca [Narbaitz and Adler, 1966; Narbaitz and DeRobertis, 1968; Gonzalez-Moran et al., 1985; Drummond, 2005]. In small chicken follicles, the single thecal layer synthesize estrogens, not the granulosa [Nitta et al., 1991a, b]. In rats, aromatase transcription increases during primordial follicle assembly [Kezele et al., 2005], whereas decreases in estrogenic signaling are suggested to regulate follicle assembly [Britt et al., 2004; Chen et al., 2007]. We observed follicle formation around S3 oocytes at 3 months after hatching concomitant with increased CYP19A1 expression compared to 1 month after hatching. This increase in CYP19A1 expression and putative resulting aromatase activity could be associated with the initiation of limited follicle formation while germ cell nests with mitotic oogonia continue to persist. 
Recent research has demonstrated substantial ovarian estrogen-activin signaling cross talk [Kipp et al., 2007a]. That is, TGF $\beta$ and steroid signaling interplay regulates follicle assembly, with estrogens impeding germ cell nest breakdown and activins promoting granulosa cell maturation and follicle assembly [Kipp et al., 2007b; Mayo et al., 2007; Trombly et al., 2009]. We observed expression patterns of $I N H B A, I N H B B$, and FST mRNA that were similar to CYP19A1 and propose that this coordinated change in expression levels relates to integrated estrogenactivin signaling that is observed in neonatal and juvenile rodent ovaries.

\section{Acknowledgements}

Continuing logistical support of our alligator research by the Florida Fish and Wildlife Conservation Commission made this study possible; specifically we thank Allan Woodward for his continued assistance with fieldwork and permitting. Grants to L.J.G. from the NIH (R21 HD047885-01; R21 ES014053-01) and the Howard Hughes Medical Institute Professors program supported this work.

\section{References}

Barakat B, O'Connor AE, Gold E, de Kretser DM, Loveland KL: Inhibin, activin, follistatin and FSH serum levels and testicular production are highly modulated during the first spermatogenic wave in mice. Reproduction 136:345-359 (2008).

-Belaid B, Richard-Mercier N, Pieau C, Dorizzi $\mathrm{M}$ : Sex reversal and aromatase in the European pond turtle: treatment with letrozole after the thermosensitive period for sex determination. J Exp Zool 290:490-497 (2001).

-Billiar RB, Zachos NC, Burch MG, Albrecht ED, Pepe GJ: Up-regulation of alpha-inhibin expression in the fetal ovary of estrogen-suppressed baboons is associated with impaired fetal ovarian folliculogenesis. Biol Reprod 68:1989-1996 (2003).

-Bozkurt HH, Aktas A, Ulkay MB, Firat UB: Sertoli cell proliferation during the post hatching period in domestic fowl. J Vet Sci 8:219222 (2007)

-Bristol-Gould SK, Kreeger PK, Selkirk CG, Kilen SM, Cook RW, et al: Postnatal regulation of germ cells by activin: The establishment of the initial follicle pool. Dev Biol 298:132-148 (2006).

Britt KL, Saunders PK, McPherson SJ, Misso ML, Simpson ER, Findlay JK: Estrogen actions on follicle formation and early follicle development. Biol Reprod 71:1712-1723 (2004).

- Buzzard JJ, Farnworth PG, de Kretser DM, O'Connor AE, Wreford NG, Morrison JR: Proliferative phase Sertoli cells display a developmentally regulated response to activin in vitro. Endocrinology 144:474-483 (2003).

- Buzzard JJ, Loveland KL, O’Bryan MK, O’Connor AE, Bakker $\mathrm{M}$, et al: Changes in circulating and testicular levels of inhibin $\mathrm{A}$ and $\mathrm{B}$ and activin A during postnatal development in the rat. Endocrinology 145:35323541 (2004).
Callebaut M: $[3 \mathrm{H}]$ Uridine incorporation during previtellogenesis and early vitellogenesis in oocytes of chick (Gallus gallus). J Embryol Exp Morphol 20:169-174 (1968a).

Callebaut M: Extracorporal development of quail oocytes. Experientia 24:1242-1243 (1968b).

Carabatsos MJ, Elvin J, Matzuk MM, Albertini DF: Characterization of oocyte and follicle development in growth differentiation factor-9-deficient mice. Dev Biol 204:373-384 (1998).

Chen Y, Jefferson WN, Newbold RR, PadillaBanks E, Pepling ME: Estradiol, progesterone, and genistein inhibit oocyte nest breakdown and primordial follicle assembly in the neonatal mouse ovary in vitro and in vivo. Endocrinology 148:3580-3590 (2007).

da Silva SJM, Bayne RAL, Cambray N, Hartley PS, McNeilly AS, Anderson RA: Expression of activin subunits and receptors in the developing human ovary: activin A promotes germ cell survival and proliferation before primordial follicle formation. Dev Biol 266: 334-345 (2004).

de Kretser DM, Buzzard JJ, Okuma Y, O'Connor AE, Hayashi T, et al: The role of activin, follistatin and inhibin in testicular physiology. Mol Cell Endocrinol 225:57-64 (2004).

Dong JW, Albertini DF, Nishimori K, Kumar TR, Lu NF, Matzuk MM: Growth differentiation factor-9 is required during early ovarian folliculogenesis. Nature 383:531-535 (1996).

Drummond AE: TGF beta signalling in the development of ovarian function. Cell Tissue Res 322:107-115 (2005).

Drummond AE, Findlay JK, Ireland JJ: Animal models of inhibin action. Seminars In Reproductive Medicine 22:243-252 (2004).

Edwards TM, Gunderson MP, Milnes MR, Guillette LJ: Gonadotropin-induced testosterone response in peripubertal male alligators. Gen Comp Endocrinol 135:372-380 (2004).
Ethier JF, Findlay JK: Roles of activin and its signal transduction mechanisms in reproductive tissues. Reproduction 121:667-675 (2001).

Ferguson MWJ, Joanen T: Temperature-dependent sex determination in Alligator mississippiensis. J Zool Lond 200:143-177 (1983).

Fitzpatrick SL, Sindoni DM, Shughrue PJ, Lane MV, Merchenthaler IJ, Frail DE: Expression of growth differentiation factor-9 messenger ribonucleic acid in ovarian and nonovarian rodent and human tissues. Endocrinology 139:2571-2578 (1998).

Forbes TR: Studies on the reproductive system of the alligator I. The effects of prolonged injections of pituitary whole gland extract in the immature alligator. Anat Rec 70:113-137 (1937).

Forbes TR: The development of the reproductive system of a lizard, Anolis carolinensis. Am J Anat 98:139-157 (1956).

-Gonzalez-Moran G, Gonzalez del Pliego M, Pedernera E: Morphological-changes in the ovary of newly hatched chickens treated with chorionic-gonadotropin during embryonicdevelopment. Gen Comp Endocrinol 59: 162-167 (1985).

Govoroun MS, Pannetier M, Pailhoux E, Cocquet J, Brillard JP, et al: Isolation of chicken homolog of the FOXL2 gene and comparison of its expression patterns with those of aromatase during ovarian development. Dev Dyn 231:859-870 (2004).

-Gribbins KM, Elsey RM, Gist DH: Cytological evaluation of the germ cell development strategy within the testis of the American alligator, Alligator mississippiensis. Acta Zoologica 87:59-69 (2006).

- Guillette LJ, Gross TS, Masson GR, Matter JM, Percival HF, Woodward AR: Developmental abnormalities of the gonad and abnormal sex-hormone concentrations in juvenile alligators from contaminated and control lakes in Florida. Environ Health Perspect 102:680-688 (1994). 
-Gunderson MP, Kohno S, Blumberg B, Iguchi T, Guillette LJ: Up-regulation of the alligator CYP3A77 gene by toxaphene and dexamethasone and its short term effect on plasma testosterone concentrations. Aquat Toxicol 78: 272-283 (2006).

- Guo QX, Kumar TR, Woodruff T, Hadsell LA, DeMayo FJ, Matzuk MM: Overexpression of mouse follistatin causes reproductive defects in transgenic mice. Mol Endocrinol 12:96106 (1998).

-Hudson QJ, Smith CA, Sinclair AH: Aromatase inhibition reduces expression of FOXL2 in the embryonic chicken ovary. Dev Dyn 233: 1052-1055 (2005).

Joanen T, McNease L: Reproductive Biology of the American Alligator in Southwest Louisiana; in Murphy JB, Collins JT (eds): Reproductive Biology and Disease of Captive Reptiles, pp 153-159 (Lawrence, Kansas 1980).

-Johnson PA, Dickens MJ, Kent TR, Giles JR: Expression and function of growth differentiation factor-9 in an oviparous species, Gallus domesticus. Biol Reprod 72:1095-1100 (2005).

-Katsu Y, Bermudez DS, Braun EL, Helbing C, Miyagawa S, et al: Molecular cloning of the estrogen and progesterone receptors of the American alligator. Gen Comp Endocrinol 136:122-133 (2004).

-Kezele PR, Ague JM, Nilsson E, Skinner MK: Alterations in the ovarian transcriptome during primordial follicle assembly and development. Biol Reprod 72:241-255 (2005).

-Kipp JJL, Kilen SM, Woodruff TK, Mayo KE: Activin regulates estrogen receptor gene expression in the mouse ovary. J Biol Chem 282:36755-36765 (2007a).

-Kipp JL, Kilen SM, Bristol-Gould S, Woodruff TK, Mayo KE: Neonatal exposure to estrogens suppresses activin expression and signaling in the mouse ovary. Endocrinology 148:1968-1976 (2007b).

-Kohno S, Bermudez DS, Katsu Y, Iguchi T, Guillette LJ: Gene expression patterns in juvenile American alligators (Alligator mississippiensis) exposed to environmental contaminants. Aquat Toxicol 88:95-101 (2008).

-Krishna TSR, Kong XP, Gary S, Burgers PM, Kuriyan J: Crystal-structure of the eukaryotic DNA-polymerase processivity factor Pcna. Cell 79:1233-1243 (1994).

Kumar TR, Varani S, Wreford NG, Telfer NM, de Kretser DM, Matzuk MM: Male reproductive phenotypes in double mutant mice lacking both FSH beta and activin receptor IIA. Endocrinology 142:3512-3518 (2001).

Lance VA: Alligator physiology and life history: The importance of temperature. Exp Gerontol 38:801-805 (2003).

Licht P, Pearson AK: Effects of mammalian gonadotropins (FSH and LH) on testes of lizard Anolis carolinensis. Gen Comp Endocrinol 13:367-381 (1969).
Loffler KA, Zarkower D, Koopman P: Etiology of ovarian failure in blepharophimosis ptosis epicanthus inversus syndrome: FOXL2 is a conserved, early-acting gene in vertebrate ovarian development. Endocrinology 144: 3237-3243 (2003).

Loveland KL, Dias V, Meachem S, Meyts ERD: The transforming growth factor-beta superfamily in early spermatogenesis: Potential relevance to testicular dysgenesis. Int J Androl 30:377-384 (2007).

Matova N, Cooley L: Comparative aspects of animal oogenesis. Dev Biol 231:291-320 (2001).

Mayo K, Jameson L, Woodruff TK: Eggs in the nest. Endocrinology 148:3577-3579 (2007).

Meachem SJ, Nieschlag E, Simoni M: Inhibin B in male reproduction: Pathophysiology and clinical relevance. Eur J Endocrinol 145:561571 (2001).

Menke DB, Page DC: Sexually dimorphic gene expression in the developing mouse gonad. Gene Expr Patterns 2:359-367 (2002).

Milnes MR, Bryan TA, Katsu Y, Kohno S, Moore BC, Iguchi T, Guillette LJ: Increased posthatching mortality and loss of sexually dimorphic gene expression in alligators (Alligator mississippiensis) from a contaminated environment. Biol Reprod 78:932-938 (2008).

Moore BC, Hamlin HJ, Botteri NL, Lawler AN, Mathavan KK, Guillette LJ: Post-hatching development of Alligator mississippiensis ovary and testis. J Morphol DOI:10.1002/ jmor.10818.

-Moore BC, Uribe-Aranzabal MC, Boggs ASP, Guillette LJ: Developmental morphology of the neonatal alligator (Alligator mississippiensis) ovary. J Morphol 269:302-312 (2008).

- Narbaitz R, Adler R: Submicroscopical observations on differentiation of chick gonads. J Embryol Exp Morphol 16:41-47 (1966).

Narbaitz R, DeRobertis EM: Postnatal evolution of steroidogenic cells in chick ovary. Histochemie 15:187-193 (1968).

-Nicholls PK, Harrison CA, Gilchrist RB, Farnworth PG, Stanton PG: Growth differentiation factor 9 (GDF9) is a germ-cell regulator of Sertoli cell function. Endocrinology 150: 2481-2490 (2009).

Nitta H, Osawa Y, Bahr JM: Immunolocalization of steroidogenic cells in small follicles of the chicken ovary - anatomical arrangement and location of steroidogenic cells change during follicular development. Domest Anim Endocrinol 8:587-594 (1991a).

Nitta H, Osawa Y, Bahr JM: Multiple steroidogenic cell-populations in the thecal layer of preovulatory follicles of the chicken ovary. Endocrinology 129:2033-2040 (1991b).

Oktay K, Schenken RS, Nelson JF: Proliferating cell nuclear antigen marks the initiation of follicular-growth in the rat. Biol Reprod 53: 295-301 (1995).
Onagbesan OM, Safi M, Decuypere E, Bruggeman V: Developmental changes in inhibin alpha and inhibin/activin beta $A$ and beta $B$ mRNA levels in the gonads during posthatch prepubertal development of male and female chickens. Mol Reprod Dev 68:319326 (2004).

- Oshima Y, Uno Y, Matsuda Y, Kobayashi T, Nakamura M: Molecular cloning and gene expression of FOXL2 in the frog Rana rugosa. Gen Comp Endocrinol 159:170-177 (2008).

-Ottolenghi C, Omari S, Garcia-Ortiz JE, Uda M, Crisponi L, et al: Foxl2 is required for commitment to ovary differentiation. Hum Mol Genet 14:2053-2062 (2005)

Ottolenghi C, Uda M, Crisponi L, Omari S, Cao A, Forabosco A, Schlessinger D: Determination and stability of sex. Bioessays 29:15-25 (2007).

- Pangas SA, Jorgez CJ, Tran M, Agno J, Li XH, et al: Intraovarian activins are required for female fertility. Mol Endocrinol 21:2458-2471 (2007).

-Pannetier M, Fabre S, Batista F, Kocer A, Renault L, et al: FOXL2 activates P450 aromatase gene transcription: towards a better characterization of the early steps of mammalian ovarian development. J Mol Endocrinol 36: 399-413 (2006)

Pepling ME: From primordial germ cell to primordial follicle: Mammalian female germ cell development. Genesis 44:622-632 (2006).

Pepling ME, de Cuevas M, Spradling AC: Germline cysts: A conserved phase of germ cell development? Trends Cell Biol 9:257-262 (1999).

- Pieau C, Dorizzi M: Oestrogens and temperature-dependent sex determination in reptiles: All is in the gonads. J Endocrinol 181: 367-377 (2004).

Raivio T, Dunkel L: Inhibins in childhood and puberty. Best Pract Res Clin Endocrinol Metab 16:43-52 (2002).

Ramaswam LS, Jacob D: Effect of testosterone propionate on urogenital organs of immature crocodile Crocodylus palustris Lesson. Experientia 21:206 (1965).

Rhen T, Metzger K, Schroeder A, Woodward R: Expression of putative sex-determining genes during the thermosensitive period of gonad development in the snapping turtle, Chelydra serpentina. Sex Dev 1:255-270 (2007).

Rooney AA, Crain DA, Woodward AR, Guillette LJ: Seasonal variation in plasma sex steroid concentrations in juvenile American alligators. Gen Comp Endocrinol 135:25-34 (2004).

Schlatt S, Weinbauer GF: Immunohistochemical localization of proliferating cell nuclear antigen as a tool to study cell-proliferation in rodent and primate testes. Int J Androl 17: 214-222 (1994). 
-Schmidt D, Ovitt CE, Anlag K, Fehsenfeld S, Gredsted L, Treier AC, Treier M: The murine winged-helix transcription factor Foxl2 is required for granulosa cell differentiation and ovary maintenance. Development 131: 933-942 (2004).

-Smith CA, Elf PK, Lang JW, Joss JMP: Aromatase enzyme-activity during gonadal sexdifferentiation in alligator embryos. Differentiation 58:281-290 (1995).

Trombly DJ, Woodruff TK, Mayo KE: Suppression of Notch signaling in the neonatal mouse ovary decreases primordial follicle formation. Endocrinology 150:1014-1024 (2009).
Uda M, Ottolenghi C, Deiana M, Kimber W, Forabosco A, et al: Foxl2 disruption causes mouse ovarian failure by pervasive blockage of follicle development. Hum Mol Genet 13: 1171-1181 (2004).

Uhlenhaut NH, Treier M: Foxl2 - function in ovarian development. Mol Genet Metab 88: 225-234 (2006).

Uribe MCA, Guillette LJ: Oogenesis and ovarian histology of the American alligator Alligator mississippiensis. J Morphol 245:225-240 (2000).

van Tienhoven A: Reproductive Physiology of Vertebrates (Cornell University Press, Ithaca 1983).

-Wang DS, Kobayashi T, Zhou LY, Paul-Prasanth B, Ijiri S, et al: Foxl2 up-regulates aromatase gene transcription in a female-specific manner by binding to the promoter as well as interacting with Ad4 binding protein/steroidogenic factor 1. Mol Endocrinol 21:712725 (2007).
Yao HHC: The Pathway to Femaleness: Current knowledge on embryonic development of the ovary. Mol Cell Endocrinol 230:87-93 (2005)

-Yao HHC, Aardema J, Holthusen K: Sexually dimorphic regulation of inhibin beta $\mathrm{B}$ in establishing gonadal vasculature in mice. Biol Reprod 74:978-983 (2006).

Yao HHC, Matzuk MM, Jorgez CJ, Menke DB, Page DC, Swain A, Capel B: Follistatin operates downstream of Wnt4 in mammalian ovary organogenesis. Dev Dyn 230:210-215 (2004). 